\title{
DECREASE OF MELTING TEMPERATURE AND SINGLE STRAND SCISSION OF DNA BY BLEOMYCIN IN THE PRESENCE OF HYDROGEN PEROXIDE
}

\author{
Kazuo Nagai*, Hideo Suzuki, Nobuo Tanaka \\ and HAMAo UMEZAwA \\ Institute of Applied Microbiology, University of Tokyo, \\ Bunkyo-ku, Tokyo, Japan
}

(Received for publication September 30, 1969)

\begin{abstract}
Effect of bleomycin and $\mathrm{H}_{2} \mathrm{O}_{2}$ on DNA was investigated. Tm of salmon sperm DNA decreased from $76^{\circ} \mathrm{C}$ to $64^{\circ} \mathrm{C}$ and that of Escherichia coli DNA from $81^{\circ} \mathrm{C}$ to $65.5^{\circ} \mathrm{C}$ in the presence of $100 \mu \mathrm{M}$ of $\mathrm{H}_{2} \mathrm{O}_{2}$ and $4 \mu \mathrm{g} / \mathrm{ml}$ of bleomycin. The change of $\mathrm{Tm}$ was more marked when the concentration of $\mathrm{H}_{2} \mathrm{O}_{2}$ or bleomycin was increased. The single strand scission of DNA was shown when the DNA was incubated at $37^{\circ} \mathrm{C}$ with $100 \mu \mathrm{M}$ of $\mathrm{H}_{2} \mathrm{O}_{2}$ and $40 \mu \mathrm{g} / \mathrm{ml}$ of bleomycin. It proceeded as the time of incubation was prolonged. The reaction of $\mathrm{H}_{2} \mathrm{O}_{2}$ at $100 \mu \mathrm{M}$ on DNA was apparent only in the presence of bleomycin.
\end{abstract}

A reaction of $\mathrm{H}_{2} \mathrm{O}_{2}$ and DNA has been known to result in release of bases, ${ }^{1,2,3}$ or altered bases, ${ }^{3,4,5)}$ breakdown of strands and decrease of $\mathrm{Tm}^{3}$. This reaction, however, requires a high concentration of $\mathrm{H}_{2} \mathrm{O}_{2}$ such as $0.1 \mathrm{M}$ and a long period of incubation in the presence of $\mathrm{FeCl}_{3}$. Low concentrations $\left(10^{-2} \sim 10^{-5} \mathrm{M}\right)$ of $\mathrm{H}_{2} \mathrm{O}_{2}$ shows no appreciable effect on the viscosity of thymus $\mathrm{DNA}^{6)}$. BoDE ${ }^{10)}$ has reported that peroxides produced in a reaction mixture containing reducing agent might cause single strand scission of DNA. As reported in previous papers, ${ }^{7,8,9)}$ bleomycin interacts with DNA which has reacted with a sulfhydryl compound, resulting in decreasing $\mathrm{Tm}$ and breaking the strands. In this connection, we investigated whether bleomycin would interact with DNA in the presence of $\mathrm{H}_{2} \mathrm{O}_{2}$. The results presented in this paper indicate that in the presence of bleomycin a low concentration of $\mathrm{H}_{2} \mathrm{O}_{2}$ decreases the melting temperature of DNA and causes scission of DNA strands. The molecular size of DNA decreased as the time of incubation was prolonged. However, unlike sulfhydryl compounds, combined effect of $\mathrm{H}_{2} \mathrm{O}_{2}$ and bleomycin on DNA appears only in their coexistence.

\section{Materials and Methods}

Materials: Bleomycin $\mathrm{A}_{2}$ (lot F-4, copper-free) was prepared by Nihon Kayaku Co., Tokyo and supplied by Dr. TAkItA, Institute of Microbial Chemistry, Tokyo. DNA of E. coli B was prepared by the method of MARMUR ${ }^{11)}$. Salmon sperm DNA was purchased from Calbiochem, Los Angeles, Calif., U.S.A.

* Present address: Laboratory of Microbiology, Department of Agricultural Chemistry, University of Tokyo, Bukyo-ku, Tokyo. 
Determination of $\mathrm{Tm}$ : The melting point of DNA was determined in a Gilford recording spectrophotometer as described previously ${ }^{7)}$. The reaction mixture containing $20 \mu \mathrm{g} / \mathrm{ml}$ of DNA in $50 \mathrm{~mm}$ Tris- $\mathrm{HCl}\left(\mathrm{pH} \mathrm{7.6)}\right.$ was kept at $37^{\circ} \mathrm{C}$ for 120 minutes with $\mathrm{H}_{2} \mathrm{O}_{2}$ and bleomycin at the concentration indicated. After the incubation, the temperature was raised at the rate of $1^{\circ} \mathrm{C}$ per 5 minutes.

Sucrose Density Gradient Centrifugation Analysis: The incubation mixture was. layered on the top of $4.8 \mathrm{ml}$ of an alkaline ( $\mathrm{pH} 12.5,0.02 \mathrm{M}$ potassium phosphate) or neutral ( $\mathrm{pH} 7.5,0.02 \mathrm{M}$ potassium phosphate) sucrose density gradient solution (5 20\%). Centrifugation was carried out in a SW $50 \mathrm{~L}$ rotor of a Beckman model L2-65B ultracentrifuge at 50,000 or $40,000 \mathrm{rev} . / \mathrm{min}$. at $20^{\circ} \mathrm{C}$. Absorbance of each fraction at $260 \mathrm{~m} \mu$ was calculated after addition of $1 \mathrm{ml}$ of water in a quartz cuvette of $1-\mathrm{cm}$ light path (Shimadzu spectrophotometer QV-50).

\section{Results}

Effect of $\mathrm{H}_{2} \mathrm{O}_{2}$ and Bleomycin on the Melting Temperature of DNA

As has been suggested by several authors, ${ }^{6,12,13)}$ low concentrations of $\mathrm{H}_{2} \mathrm{O}_{2}$ failed to show any effect on Tm of DNA. However, a marked decrease of $\mathrm{Tm}$ was observed in the presence of $\mathrm{H}_{2} \mathrm{O}_{2}$ and bleomycin. This effect became more apparent as the concentration of either compound was increased. The increase of concentration of $\mathrm{H}_{2} \mathrm{O}_{2}$ affected it more strongly than that of bleomycin. Similar results were obtained on both DNA's of salmon sperm and $E$. coli B. When salmon sperm DNA was incubated with $\mathrm{H}_{2} \mathrm{O}_{2}$ and thereafter catalase was added together with bleomycin just before the determination of $\mathrm{Tm}$, then the shift of $\mathrm{Tm}$ was only $3.5^{\circ} \mathrm{C}$. On the other hand, when $\mathrm{H}_{2} \mathrm{O}_{2}$ was added after the incubation of DNA and bleomycin and then the $\mathrm{Tm}$ was determined, the shift was $9^{\circ} \mathrm{C}$. Moreover, the shift was $14^{\circ} \mathrm{C}$ when bleomycin and $\mathrm{H}_{2} \mathrm{O}_{2}$ were present throughout the incubation and determination of the melting point.

In an experiment, DNA was incubated with $\mathrm{H}_{2} \mathrm{O}_{2}$, the reaction mixture was dialyzed, and the Tm of the DNA was determined in the presence or absence of bleomycin.

Table 1. Shift of Tm of DNA in the presence of $\mathrm{H}_{2} \mathrm{O}_{2}$ and bleomycin

\begin{tabular}{|c|c|c|c|c|c|c|}
\hline \multirow{3}{*}{$\begin{array}{l}\text { Origin } \\
\text { of } \mathrm{DNA}\end{array}$} & \multirow{3}{*}{$\begin{array}{l}\text { Concen- } \\
\text { tration } \\
\text { of } \mathrm{H}_{2} \mathrm{O}_{2} \\
(\mu \mathrm{M})\end{array}$} & \multicolumn{5}{|c|}{ Concentration of bleomycin } \\
\hline & & \multirow{2}{*}{$\begin{array}{c}0 \\
\mu \mathrm{g} / \mathrm{ml} \\
\mathrm{Tm}\end{array}$} & \multicolumn{2}{|c|}{$4 \mu \mathrm{g} / \mathrm{ml}$} & \multicolumn{2}{|c|}{$40 \mu \mathrm{g} / \mathrm{ml}$} \\
\hline & & & $\mathrm{Tm}$ & $\Delta \mathrm{Tm}$ & $\mathrm{Tm}$ & $\Delta \mathrm{Tm}$ \\
\hline E. coli B & $\begin{array}{r}0 \\
10 \\
100\end{array}$ & $\begin{array}{l}81.0 \\
81.0 \\
81.0\end{array}$ & $\begin{array}{l}81.0 \\
77.0 \\
65.5\end{array}$ & $\begin{array}{r}0 \\
-\quad 4.0 \\
-15.5\end{array}$ & $\begin{array}{l}81.0 \\
76.0 \\
63.0\end{array}$ & $\begin{array}{r}0 \\
-5.0 \\
-18.0\end{array}$ \\
\hline \multirow{3}{*}{$\begin{array}{l}\text { Salmon } \\
\text { sperm }\end{array}$} & $\begin{array}{r}0 \\
10\end{array}$ & $\begin{array}{l}76.0 \\
76.0\end{array}$ & $\begin{array}{l}76.0 \\
73.0\end{array}$ & $\begin{array}{r}0 \\
-3.0\end{array}$ & $\begin{array}{l}76.0 \\
71.5\end{array}$ & $\begin{array}{r}0 \\
-\quad 4.5\end{array}$ \\
\hline & 100 & $\begin{array}{l}76.0 \\
76.0 \\
76.0 \\
76.0 \\
76.0 \\
76.0\end{array}$ & 64.0 & -12.0 & $\begin{array}{l}62.0^{\mathrm{a}} \\
76.0^{\mathrm{a}} \\
70.0^{\mathrm{b}} \\
74.5^{\mathrm{c}} \\
72.5^{\mathrm{d}} \\
67.0^{\mathrm{e}}\end{array}$ & $\begin{array}{r}-14.0 \\
0 \\
-6.0 \\
-1.5 \\
-3.5 \\
-9.0\end{array}$ \\
\hline & & $\begin{array}{l}76.0 \\
76.0\end{array}$ & & & $\begin{array}{l}71.0^{\mathrm{f}} \\
71.0^{\mathrm{g}}\end{array}$ & $\begin{array}{l}-5.0 \\
-5.0\end{array}$ \\
\hline
\end{tabular}

The reaction mixture was incubated for 120 minutes at $37^{\circ} \mathrm{C}$ and thereafter the temperature was raised at the rate of $1^{\circ} \mathrm{C}$ per 5 minutes.

a: DNA was incubated with $\mathrm{H}_{2} \mathrm{O}_{2}(100 \mu \mathrm{M})$ and dialyzed against 100 vol. of $50 \mathrm{~mm}$ Tris $-\mathrm{HCl}(\mathrm{pH} 7.6)$ at $4^{\circ} \mathrm{C}$ for 12 hours. Bleomycin was added before Tm determination.

$\mathrm{b}$ : DNA was incubated with bleomycin $(40 \mu \mathrm{g} / \mathrm{ml})$ and dialyzed against 100 vol. of $50 \mathrm{~mm}$ Tris-HC1 (pH 7.6) at $4^{\circ} \mathrm{C}$ for 2 hours and against the same volume of the same buffer for another 10 hours. $\mathrm{H}_{2} \mathrm{O}_{2}$ was introduced before determination of $\mathrm{Tm}$.

c : $1 \mu \mathrm{g}$ of catalase was added before the incubation.

d: DNA and $\mathrm{H}_{2} \mathrm{O}_{2}$ were kept at $37^{\circ} \mathrm{C}$ for 120 minutes and then bleomycin and $1 \mu \mathrm{g}$ of catalase were added to the reaction mixture.

e: $\mathrm{H}_{2} \mathrm{O}_{2}$ was added after the incubation of DNA and bleomycin.

$\mathrm{f}$ : $\mathrm{Tm}$ was determined in the presence of $1 \mathrm{~mm}$ of 2 mercaptoethanol in place of $\mathrm{H}_{2} \mathrm{O}_{2}$.

$\mathrm{g}: 1 \mu \mathrm{g}$ of catalase was added to the mixture before the incubation. 
Fig. 1. Sedimentation analysis of DNA treated with $\mathrm{H}_{2} \mathrm{O}_{2}$ and bleomycin.

$200 \mu \mathrm{g} / \mathrm{ml}$ of $E$. coli B DNA was incubated at $37^{\circ} \mathrm{C}$ in $50 \mathrm{~mm}$ Tris- $\mathrm{HCl}(\mathrm{pH} 7.6$ ) containing $100 \mu \mathrm{M}$ of $\mathrm{H}_{2} \mathrm{O}_{2}$ with or without bleomycin. $0.1 \mathrm{ml}$ of reaction mixture was layered on 5 to $20 \%$ linear neutral (a) or alkaline (b) sucrose densityrev./min. for 180 minutes at $20^{\circ} \mathrm{C}$

I : Incubated in the absence of bleomycin for 120 minutes and then dialyzed against $50 \mathrm{~mm}$ Tris- $\mathrm{HCl}\left(\mathrm{pH}\right.$ 7.6) containing $100 \mu \mathrm{M}$ of $\mathrm{H}_{2} \mathrm{O}_{2}$ for 12 hours at $0^{\circ} \mathrm{C}$.

II : Incubated in the presence of bleomycin for 120 minutes and dyalyzed as described above.

III : Incubated in the presence of bleomycin for 120 minutes and stored at $0^{\circ} \mathrm{C}$ for 12 hours without dialysis.
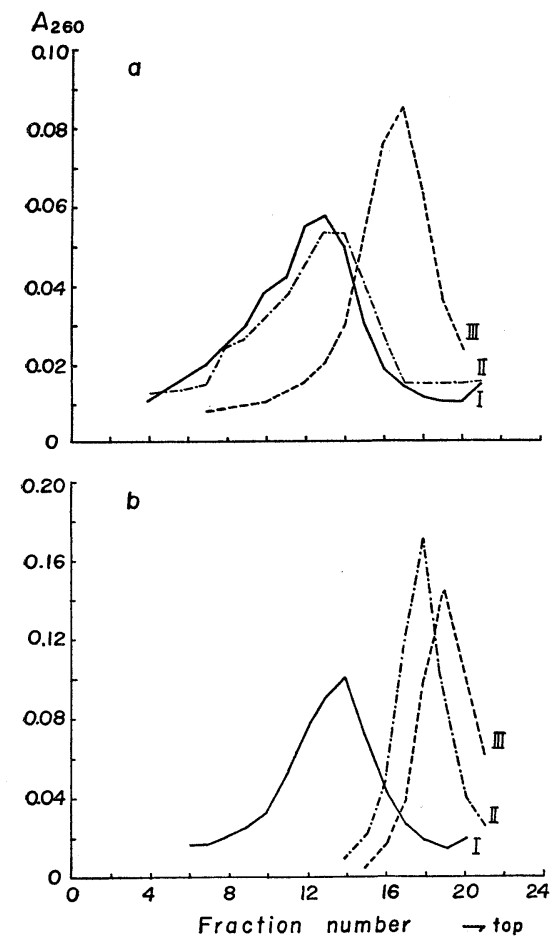
gradient. Centrifugation was carried out at 40,000

Fig. 2. Decrease of molecular size of DNA after the treatment with $\mathrm{H}_{2} \mathrm{O}_{2}$ and bleomycin for different periods.

E. coli B DNA was incubated as in Fig. 1. Reaction was stopped with addition of $1 \mu \mathrm{g}$ of catalase to the $0.5 \mathrm{ml}$ of reaction mixture. $0.1 \mathrm{~m} 1$ of the reaction mixture was analyzed by alkaline sucrose density-gradient $(5 \sim 20 \%)$ centrifugation which was carried out at $50,000 \mathrm{rev} . / \mathrm{min}$, for 150 minutes at $20^{\circ} \mathrm{C}$. DNA was incubated in the absence of bleomycin for 6 hours (a) or in the presence of bleomycin for 1.5 hours (b), 3 hours (c) and 6 hours (d).

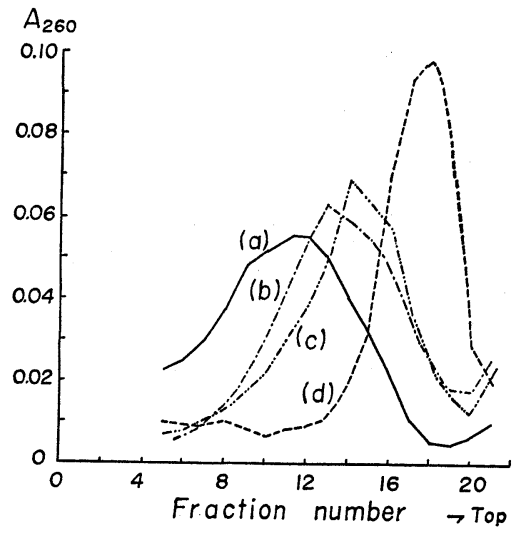

In this case no change of $\mathrm{Tm}$ was observed. In another experiment, DNA was incubated with bleomycin, the reaction mixture was dialyzed, $\mathrm{H}_{2} \mathrm{O}_{2}$ was added and the $\mathrm{Tm}$ was determined, then, $\mathrm{Tm}$ of DNA decreased by $6^{\circ} \mathrm{C}$. Bleomycin, which has a relatively large molecular weight such as 1,300 and basic functions, is thought to remain in a trace amount after the dialysis and to cause a small decrease of $\mathrm{Tm}$ in the presence of $\mathrm{H}_{2} \mathrm{O}_{2}$. As shown in Table 1 , the difference of the effect between $40 \mu \mathrm{g} / \mathrm{ml}$ and $4 \mu \mathrm{g} / \mathrm{ml}$ of bleomycin is very slight.

The results of the experiments are summarized in Table 1 . Besides the results of experiments described above, Table 1 includes the result of an experiment testing combined effect of 2-mercaptoethanol and bleomycin on salmon sperm DNA in the presence or the absence of catalase. Catalase shows no influence on the combined effect of the sulfhydryl compound and bleomycin.

\section{Strand Scission of DNA by $\mathrm{H}_{2} \mathrm{O}_{2}$ and Bleomycin}

The molecular size of DNA was analyzed by sucrose density gradient centrifugation after the incubation with $\mathrm{H}_{2} \mathrm{O}_{2}$ and bleomycin. When the DNA was incubated with $\mathrm{H}_{2} \mathrm{O}_{2}$ and bleomycin for 120 minutes at $37^{\circ} \mathrm{C}$ and dialyzed against the buffer containing $\mathrm{H}_{2} \mathrm{O}_{2}$ at $0^{\circ} \mathrm{C}$, no significant change of molecular size was shown by neutral sucrose density gradient centrifugation (Fig. 1-a). However, as presented in Fig. 1-b, 
a decrease of molecular size was revealed by alkaline sucrose density gradient analysis. This indicates that single strand breaks occurred during the incubation. As shown in Fig. 1-a, when the reaction mixture was kept at $0^{\circ} \mathrm{C}$ for 12 hours after the incubation, then the strand breaks were shown even by neutral sucrose density gradient analysis. It was also shown that the number of strand scission increased as the time of incubation was prolonged (Fig. 2). No change in DNA molecular size was observed during 12-hour incubation with either $\mathrm{H}_{2} \mathrm{O}_{2}$ or bleomycin alone.

\section{Discussion}

As shown in previous papers, bleomycin interacts with DNA in the presence of a sulfhydryl compound, resulting in decrease of $\mathrm{Tm}^{7,8)}$ and breakdown of strands ${ }^{8,9)}$. The breakdown of strands was more markedly shown when molecular size of DNA was examined after its dialysis. As to the sequence of the reaction it was also shown ${ }^{7)}$ that the reaction must occur first between DNA and a sulfhydryl compound and finally bleomycin. When the present results are compared with these facts, the reactions of $\mathrm{H}_{2} \mathrm{O}_{2}$ and sulfhydryl compound with DNA are different in following points:

(1) Decrease of Tm of DNA was observed only in the coexistence of bleomycin and $\mathrm{H}_{2} \mathrm{O}_{2}$, but in the case of a sulfhydryl compound the decrease of $\mathrm{Tm}$ was observed at the same extent when the reaction mixture containing DNA and a sulfhydryl compound was. dialyzed after the incubation and thereafter bleomycin was added.

(2) The molecular size of DNA decreased as the time of incubation was prolonged in the presence of bleomycin and $\mathrm{H}_{2} \mathrm{O}_{2}$. On the other hand, with a sulfhydryl compound, the prolonged incubation did not increase the effect of bleomycin causing breakdown of DNA strands. These indicate that a sulfhydryl compound reacts with DNA during the incubation without bleomycin and this reaction is not reversed even when a sulfhydryl compound is removed by dialysis whereas the reaction between low concentration of $\mathrm{H}_{2} \mathrm{O}_{2}$ and DNA occurs apparently only in the presence of bleomycin or is reversed when $\mathrm{H}_{2} \mathrm{O}_{2}$ is removed by dialysis.

The inactivation of pneumococcal transforming activity by ascorbate was suggested to be caused by the peroxide produced during the course of ascorbate autoxidation ${ }^{14)}$. Recently single strand scission of DNA has been reported ${ }^{10,15)}$ to be caused by several reducing agents such as ascorbate, dithiothreitol, 2-mercaptoethanol, reduced diphosphopyridine nucleotide and 4-hydroxyquinoline-N-oxide, and the role of $\mathrm{H}_{2} \mathrm{O}_{2}$ produced from these reducing agents and oxygen was suggested for the strand scission. However, present results indicate that the strand scission of DNA by a sulfhydryl compound and bleomycin is not caused via the reaction of $\mathrm{H}_{2} \mathrm{O}_{2}$.

According to Phaese et al. ${ }^{3)}$, the reaction of $\mathrm{H}_{2} \mathrm{O}_{2}$ with polydeoxynucleotide initiates with the attack of anomeric carbon of deoxyribose by hydroxyl free radical and the reaction in the early steps, that is, before release of the base, are reversible. Though the reaction mechanism among DNA, $\mathrm{H}_{2} \mathrm{O}_{2}$ and bleomycin remains to be determined, it may be considered that bleomycin might interact with a reaction product of DNA and $\mathrm{H}_{2} \mathrm{O}_{2}$ which is still in the reversible steps as described above. In this connection, it may be worthy to cite a paper ${ }^{12}$ ) which reported binding of hydrocarbons to DNA in the presence of $\mathrm{H}_{2} \mathrm{O}_{2}$.

As reported in a previous paper ${ }^{9)}$, scission of a DNA strand is observed in cells treated with bleomycin. It is not certain, which type of the reactions, that is, those among DNA, $\mathrm{H}_{2} \mathrm{O}_{2}$ and bleomycin or those among DNA, sulfhydryl compounds and bleomycin woud play a role in cells, causing the strand scission. If the former type is predominant in the cells, it is interesting in connection with the effect of bleomycin against cancer cells ${ }^{16,17)}$ in which catalase is generally decreased. 


\section{References}

1) Uchida, Y.; H. Shigematsu \& K. Yamafuji: The mode of action of hydrogen peroxide on deoxyribonucleic acid. Enzymologia $29: 369 \sim 376,1965$

2) Yamafuji, K. \& Y. Uchida: Liberation of adenine from deoxyribonucleic acid by hydrogen peroxide. Nature $209: 301 \sim 302,1966$

3) Phaese, H. \& E. Freese: Chemical analysis of DNA alterations. I. Base liberation and backbone breakage of DNA and oligodeoxyadenylic acid induced by hydrogen peroxide and hydroxylamine. Biochim. Biophys. Acta $155: 476 \sim 490,1968$

4) Phaese, H.; E. Freese \& M. S. Melzer: Chemical analysis of DNA alterations. II. Alteration and liberation of bases of deoxynucleotides and deoxynucleosides induced by hydrogen peroxide and hydroxylamine. Biochim. Biophys. Acta $155: 491 \sim 504,1968$

5) Phaese, H.: Chemical analysis of DNA alterations. III. Isolation and characterization of adenine oxidation products obtained from oligo- and monodeoxyadenylic acids treated with hydroxyl radicals. Biochim. Biophys. Acta $166: 311 \sim 326,1968$

6) Taylor, B.; J. P. Greenstein \& A. Hollander: Effects of X-radiation on sodium thymus nucleate. Arch. Biochem. Biophys. $179: 19 \sim 31,1948$

7) Nagai, K.; H. Yamaki, H. Suzuki, N. Tanaka \& H. Umezawa: The combined effects of bleomycin and sulfhydryl compounds on the thermal denaturation of DNA. Biochim. Biophys. Acta 179 : 165 171, 1969

8) Nagai, K.; H. Suzuki, N. Tanaka \& H. Umezawa: Decrease of melting temperature and single strand scission of DNA by bleomycin in the presence of 2-mercaptoethanol. J. Antibiotics $22: 569 \sim 573,1969$

9) Suzuki, H.; K. Nagai, H. Yamaki, N. Tanaka \& H. Umezawa: On the mechanism of action of bleomycin: Scission of DNA strands in vitro and in vivo. J. Antibiotics $22: 446 \sim 448,1969$

10) Bode, V.C.: Single-strand scissions induced in circular and linear DNA by the presence of dithiothreitol and other reducing agents. J. Mol. Biol. $26: 125 \sim 129,1967$

11) MARMUR, J.: A procedure for the isolation of deoxyribonucleic acid from micro-organisms. J. Mol. Biol. $3: 208 \sim 218,1961$

12) Morreal, C. H.; T. L. Dao, K. Esking, C. L. King \& J. Dienstag: Peroxide induced binding of hydrocarbons to DNA. Biochim. Biophys. Acta $169: 224 \sim 229,1968$

13) Schweitz, H. \& D. Luzzatr: Action de l'eau oxygénée sur les bases puriques et pyrimidiques et leurs déoxyribonucléotides et sur l'acide désoxyribonucléique. J. Chim. Phys. $60: 1173 \sim$ 1178,1963

14) MCCARTY, M.: Reversible inactivation of the substance inducing transformation of pneumococcal types. J. Exp. Med. $81: 501 \sim 514,1945$

15) Sugimura, T.; H. Otake \& T. Matsushima: Single strand scissions of DNA caused by a carcinogen, 4-hydroxyaminoquinoline-1-oxide. Nature $218: 392,1968$

16) Ishizuka, M.; H. Takayama, T. Takeuchi \& H. Umezawa: Activity and toxicity of bleomycin. J. Antibiotics, Ser. A $20: 15 \sim 24,1967$

17) Umezawa, H.; M. Ishizuka, K. Kimura, J. Imanaga \& T. Takeuchi: Biological studies on individual bleomycins. J. Antibiotics $21: 592 \sim 602,1968$ 